\title{
Penerapan Metode Analytic Hirerarchy Process (AHP) Untuk Pemilihan Kabid Pendapatan Badan Keuangan Daerah Kota Padangsidempuan
}

\author{
Susriyanti ${ }^{1}$, Fitri Yeni ${ }^{2}$, Erwin H Harahap ${ }^{3}$, Sarjon Defit ${ }^{4}$ \\ Universitas Putra Indonesia YPTK Padang \\ Telp. (0751) 776666, Fax. 71913 \\ susriyanti@upiyptk.ac.id, fitri_yeni@upiyptk.ac.id, erwinhrp5@gmail.com \\ sarjondefit@upiyptk.ac.id
}

\begin{abstract}
Proposing and voting kabid income BKD city of Padang Sidempuan is done through a series of process. The selection process can be done by observing the variety of considerations of various elements of the assessment. So that decision-makers can be easier in your selections so very necessary computerized decision support systems. In developing decision support system used method of Analitycal Hierarchy Process (AHP) by making a matrix comparison of paired and matrix of criteria so that retrieved the value of the total in use as a base in perengkingan. The input data retrieved from secondary data contained in the assessment of the achievements of the work of employees (PPKP). In PPKP element assessed consists of two components, namely the employment Target employees (SKP) and Work Behavior (PK). AHP method to be performed on the body of the Regional city of Padang Sidempuan Finance this is a work Behavior (PK), with 6 criteria i.e. orientation service, integrity, commitment, discipline, cooperation, and leadership. Candidates will be assessed the Kabid consists of 4 employees. The results obtained from the process by using AHP method was obtained that information from the four candidate kabid, then candidate $A$ kabid is the most viable candidate due to A gain the most value from other candidates i.e. 0.330715 or $33.07 \%$.
\end{abstract}

Keywords: AHP, kabid candidate criteria, Kabid Income Proposal

Abstrak- Pengusulan dan pemilihan kabid pendapatan BKD kota Padang Sidempuan dilakukan melalui serangkaian proses. Proses pemilihan dapat dilakukan dengan memperhatikan berbagai pertimbangan dari berbagai unsur penilaian. Agar para pengambil keputusan bisa lebih mudah dalam menetapkan pilihan maka sangat diperlukan sistem pendukung keputusan yang terkomputerisasi. Dalam membangun sistem pendukung keputusan digunakan metode Analitycal Hierarchy Process (AHP) dengan membuat matriks perbandingan berpasangan dan matriks kriteria sehingga diperoleh nilai total yang di gunakan sebagai dasar dalam perengkingan. Data-data input diperoleh dari data sekunder yang terdapat dalam Penilaian Prestasi Kerja Pegawai (PPKP). Dalam PPKP unsur yang dinilai terdiri dari dua komponen yaitu Sasaran Kerja Pegawai (SKP) dan Perilaku Kerja (PK). Metode AHP yang akan dilakukan di Badan Keuangan Daerah Kota Padang Sidempuan ini adalah Perilaku Kerja (PK) dengan 6 kriteria yaitu orientasi pelayanan, integritas, komitmen, disiplin, kerjasama, dan kepemimpinan. Calon Kabid yang akan dinilai terdiri dari 4 orang pegawai. Hasil yang didapat dari proses dengan menggunakan metode AHP ini diperoleh informasi bahwa dari ke empat kandidat calon kabid, maka kandidat calon kabid A adalah yang paling layak dikarenakan kandidat A memperoleh nilai yang paling tinggi dari kandidat lainnya yaitu 0.330715 atau 33,07\%.

Kata Kunci: AHP, kriteria kandidat kabid, Usulan Kabid Pendapatan 


\section{PENDAHULUAN}

Kabid Pendapatan merupakan bagian dari jajaran manajerial tingkat middle pada Badan Keuangan Daerah di kota Padangsidempuan. Padangsidempuan merupakan sebuah kabupaten yang ada dalam wilayah propinsi Sumatera Utara. Kabid Pendapatan merupakan suatu jajaran bagian yang membantu tugas-tugas pada Badan Keuangan Daerah. Untuk pemilihan Kabid di Bagian Keuangan Daerah Kota Padangsidempuan selama ini menggunakan sistem yang manual dengan menggunakan unsur penilaian dari Sasaran Kerja Pegawai (SKP) dan Perilaku Kerja. Saat ini tim penilai untuk pemilihan Kabid Pendapatan mencoba penerapan metode AHP untuk membantu memberikan penilaian cepat, terstruktur dan sistematis guna membantu pimpinan perusahaan dalam mengambil keputusan. Dan tidak tertutup kemungkinan bahwa untuk decision making berikutnya pada pemilihan kabid-kabid lainnya ataupun pada masalah-masalah lainnya Badan Keuangan Daerah Kota Padangsidempuan akan menggunakan metode AHP juga. Metode AHP bisa digunakan untuk sistem perekrutan pegawai, mutasi, promosi, ataupun masalah-masalah lainnya yang ada dalam perusahaan.

Metode AHP merupakan salah satu metode komputasi yang cukup berkembang saat ini sebagai salah satu metode sistem pengambilan keputusan (Decision Support System). "Sistem Pendukung Keputusan (SPK) atau Decision Support System (DSS) merupakan suatu sistem interaktif yang membantu pengambilan keputusan untuk memecahkan masalah-masalah yang sifatnya semi terstruktur dan tidak terstruktur" [1]. Penyelesian dengan menggunakan sistem ini dapat dilakukan dengan berjenjang dengan mengurutkan jenjang hirarki dari "goal" pada jenjang pertama, "criteria" pada jenjang ke dua, dan "alternative" pada jenjang ke tiga. Prinsip kerja AHP adalah penyederhanaan suatu persoalan kompleks yang tidak terstruktur menjadi bagian-bagiannya, serta menata dalam suatu hirarki. Kemudian tingkat kepentingan setiap variabel tersebut secara relatif dibandingkan dengan dengan variabel lain. Dari berbagai pertimbangan tersebut dilakukan sintesa untuk menetapkan variabel yang memiliki prioritas tinggi dan berperan untuk mempengaruhi hasil pada sistem tersebut (Suryadi, 2001).

[2] melalukan penelitian tentang "Aplikasi Sistem Pendukung Keputusan Guru Terbaik Berdasarkan Kinerja dengan Metode Analytical Hierarchy Process (AHP)", menggunakan 15 kriteria dan 4 orang calon kandidat terpilih. Dan metode AHP dapat dijadikan pendekatan untuk memilih Guru Terbaik di sekolah tersebut. Form Penilaian Guru yang mempunyai penilaian berkisar 1 - 4 sesuai standar yang telah ditetapkan oleh Yayasan Lentera Insan sebagai pihak pengelola sekolah. [3] melakukan penelitian Pada RSUD Serang dengan menggunakan metode AHP yang semula RSUD Serang hanya menggunakan metode manual untuk melakukanb penilaian kinerja sehingga penilaian menjadi lambat dan tidak akurat serta juga sering subjektif. Hasil penelitian menunjukkan bahwa sistem yang dibangun mampu memberikan hasil perhitungan secara otomatis sesuai dengan hasil perhitungan yang dilakukan secara manual. Setelah dilakukan penilaian pada aplikasi SPK penilaian kinerja pegawai dengan 5 pegawai didapat hasil akhir dengan skor tertinggi 0,4481 pada pegawai Ratnawati.

[4] melakukan penelitian tentang "Sistem Pendukung Keputusan Untuk Menentukan Kualitas Stasiun Televisi Sebagai Konsumsi Terbaik Bagi Masyarakat Dengan Menggunakan Metode AHP" Analisa data dalam penelitian ini dilakukan 
dengan cara membandingkan antara stasiun televisi yang ada di Indonesia, berdasarkan edukatif, inovatif, dan sumber daya manusia (kru televisi) yang terdapat pada masing-masing stasiun televisi. Hasil dari analisa metode AHP ini menjadi kesimpulan yang dapat membantu masyarakat untuk mengetahui stasiun televisi yang terbaik sebagai konsumsi publik yang cenderung membutuhkan informasi, pengetahuan dan hiburan. Dari hasil penelitian dapat diketahui bahwa stasiun televisi berkualitas terbaik untuk dikonsumsi oleh masyarakat adalah Trans yang terdiri dari Trans 7 dan Trans TV.

\section{METODE PENELITIAN}

Penelitian ini merupakan penelitian secara deskriptif kuantitatif. Penelitian deskriptif merupakan penelitian yang dilakukan dengan memberikan gambaran atau uraian tentang suatu kegiatan sejelas mungkin tanpa adanya perlakuan terhadap objek yang akan diteliti. Penelitian kuantitatif dilakukan dengan angkaangka yang diolah secara statistik. Objek pada penelitian ini adalah Badan Keuangan Daerah Kota Padangsidempuan dengan subjek penelitian adalah calon Kabid Pendapatan. Calon Kabid Pendapatan di sini terdiri dari 4 orang pegawai sebagai calon Kabid yang akan dijadikan sampel dalam penelitian ini. Sedangkan popolasinya adalah seluruh pegawai yang ada di bawah Badan Keuangan Daerah Kota Padangsidempuan. Data primer adalah data yang diperoleh secara langsung oleh peneliti dan belum tersedia atau tersaji sebelumnya. Data primer diperoleh melalui observasi dan wawancara dengan Kadis Keuangan BPK Kota Padangsidempuan. Sedangkan data sekunder merupakan data-data yang sudah tersedia sebelumnya seperti data laporan hasil PPKP instansi, buku-buku kepustakaan, jurnal-jurnal ilmiah, artikel, dan lain-lain. Konsep metode AHP adalah merubah nilai-nilai kualitatif menjadi nilai kuantitatif. Ada beberapa prinsip yang harus dipahami dalam pemyelesaian metode AHP ini, yaitu:

\section{Decomposition}

Yaitu memecahkan persoalan yang utuh menjadi unsur-unsurnya yang saling berhubungan. Jika ingin mendapatkan hasil yang akurat, pemecahan juga dilakukan terhadap unsur-unsurnya sampai tidak mungkin dilakukan pemecahan lebih lanjut, sehingga didapatkan beberapa tingkatan dari persoalan tadi. Struktur hirarki keputusan tersebut dapat dikategorikan sebagai complete dan incomplete. Dikatakan complete jika semua elemen pada suatu tingkat memiliki hubungan pada semua elemen yang ada pada tingkat berikutnya, sementara incomplete adalah kebalikannya.

Bentuk struktur dekomposisi adalah:

Tingkat pertama: Tujuan Keputusan (Goal)

Tingkat ke dua : Kriteria-kriteria

Tingkat ke tiga : Alternatif-alternatif

Hirarki pendifisian masalah dalam penelitian ini berdasarkan literatur teori yang telah dipaparkan sebelumnya akan disajikan pada gambar 1 di bawah ini: 


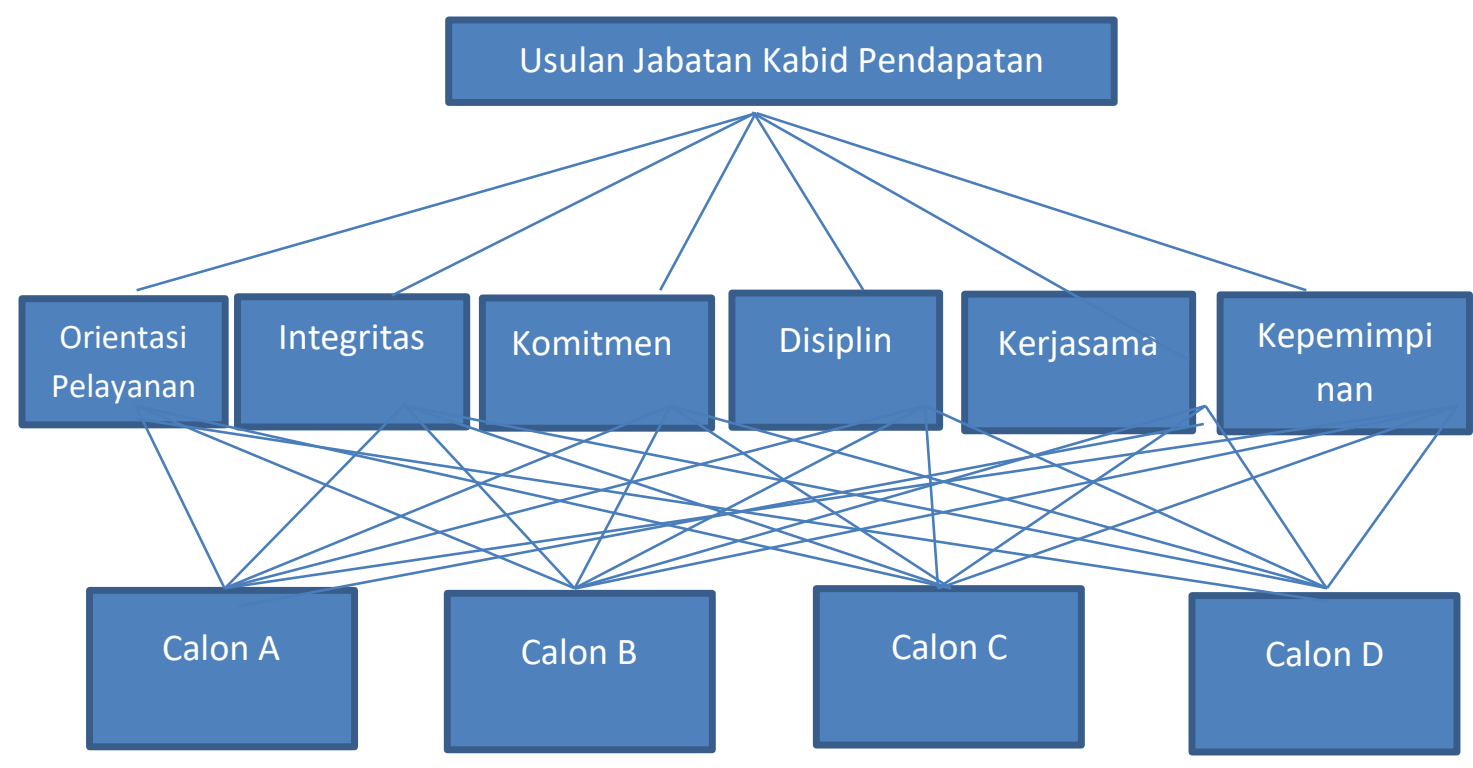

Gambar 1. Hierarki pendifinisian masalah

Keterangan:

a. Goal : Usulan Jabatan Kabid Pendapanan

b. Kreteria : Perilaku Kerja Pegawai

c. Alternatif : Calon-calon Kabid Pendapatan

\section{Comparatif Judgement}

Membuat penilaian tentang kepentingan relatif dua elemen pada suatu tingkat tertentu dalam kaitannya dengan tingkat di atasnya. Penilaian ini merupakan inti dari AHP, karena akan memberikan pengaruh terhadap prioritas elemen-elemen.

3. Synthesis of Priority

Dari setiap pairwise comparison kemudian dicari eigen vector-nya untuk mendapatkan local priority. Karena matriks pairwise comparison terdapat pada setiap tingkat, maka untuk mendapatkan global priority harus dilakukan sintesa diantara local priority. Prosedur melakukan sintesis berbeda menurut bentuk hirarki. Pengurutan elemen-elemen menurut kepentingan relatif memalui prosedur sintesa dinamakan priority setting.

\section{Logical Consistency}

Konsistensi memiliki dua makna. Pertama adalah bahwa objek-objek yang serupa dapat dikelompokkan sesuai dengan keseragaman. Ke dua adalah menyangkut tingkat hubungan antara objek-objek yang didasarkan pada kriteria tertentu.

Kriteria dan alternatif akan dinilai melalui perbandingan berpasangan. Menurut [5], untuk berbagai persoalan, skala 1 sampai 9 adalah skala terbaik dalam mengekspresikan pendapat. Nilai dan definisi pendapat kualitatis dari skala perbandingan Saaty dapat dilihat pada tabel 1 di bawah ini: 
Tabel 1. Skala Penilaian Perbandingan Berpasangan

\begin{tabular}{|c|l|}
\hline $\begin{array}{c}\text { Intensitas } \\
\text { Kepentingan }\end{array}$ & \multicolumn{1}{c|}{ Keterangan } \\
\hline 1 & Kedua elemen sama penting \\
\hline 3 & Elemen yang satu sedikit lebih penting daripada elemen yang lain \\
\hline 5 & Elemen yang satu lebih penting dari elemen yang lainnya \\
\hline 7 & Satu elemen jelas lebih penting daripada elemen lainnya \\
\hline 9 & Satu elemen mutlak penting dari elemen lainnya \\
\hline $2,4,6,8$ & Nilai-nilai antara dua pertimbangan yang berdekatan \\
\hline Kebalikan & $\begin{array}{l}\text { Jika aktivasi i mendapatkan satu angka dibandingkan aktivasi } \mathrm{j}, \text { maka } \mathrm{j} \\
\text { memiliki nilai kebalikan dibandingkan aktivitas i }\end{array}$ \\
\hline
\end{tabular}

\section{HASIL DAN PEMBAHASAN}

Dalam melakukan pemilihan Kepala Bidang diperlukan suatu sistem penilaian yang tepat. Penilaian adalah suatu standar yang dapat dijadikan acuan oleh pengguna sistem penilaian tersebut dalam mengambil keputusan untuk kepentingan organisasi. Penilaian di Badan Keuangan Daerah Kota Padangsidempuan menggunakan standar PPKP (Penilaian Prestasi Kerja Pegawai) dengan dua unsur penilaian yaitu Sasaran Kerja Pegawai dengan komposisi 60\% dari total nilai yang didapatkan, dan dari Perilaku Kerja dengan komposisi 40\% dari total nilai yang didapatkan.

Dalam penilaian SKP, nilai capaian atau total nilai didapat dari penilaian kegiatan tugas jabatan sebagai berikut:

a. Membuat rencana kerja berdasarkan peraturan yang berlaku untuk pedoman pelaksanaan tugas.

b. Mengkoordinir kegiatan pengumpulan dan pengolahan serta pencatatan penerimaan yang berkaitan dengan pajak daerah, retribusi daerah, hasil penhelolaan kekayaan daerah untuk mengetahui target penerimaan dalam penyusunan APBD.

c. Membagi tugas kepada bawahan sesuai seksi masing-masing agar pelaksanaannya dapat berjalan lancar.

d. Mengelola kegiatan pencatatan PAD sesuai dengan jenisnya untuk kelancaran pelaksanaan tugas.

e. Melaksanakan koordinasi dengan instansi terkait sesuai bidang tugasnya dalam rangka singkronisasi pelaksanaan tugas.

f. Melaksanakan tugas kedinasan lainnya sesuai instruksi atasan agar tugas terbagi habis.

g. Membuat hasil pelaksanaan tugas kepada atasan secara berkala sebagai bahan untuk penyesuaian program selanjutnya.

Untuk menyempurnakan penilaian kegiatan tugas jabatan, diberikan penilaian lain dari tugas tambahan dan kreatifitas. Ini merupakan bagian penilaian dari SKP (Sasaran Kerja Pegawai). Sedangkan penilaian Perilaku Kerja (PK) pegawai pada Badan Keuangan Daerah Kota Padangsidempuan dilakukan dengan menggunakan acuan penilaian dari beberapa standar penilaian yang telah ditetapkan oleh pemerintah daerah setempat sesuai dengan peraturan perundangundangan kepegawaian yang sama untuk seluruh Indonesia berdasarkan peraturan pemerintah pusat, yaitu:

a. Orientasi Pelayanan 


\section{b. Integritas}

c. Komitmen

d. Disiplin

e. Kerjasama

f. Kepemimpinan

Dari kedua kelompok penilaian PPKP tersebut yang akan dianalisis menggunakan metode AHP adalah dari kelompok penilaian Perilaku Kerja yang terdiri dari 6 kriteria penilaian di atas. Untuk pembahasan hasil dari penggunanaan metode AHP ini pada pemilihan calon Kabid Pendapatan di Kota Padangsidempuan ini adalah sebagai berikut:

\subsection{Hasil Matrik Penilaian Kriteria}

Hasil matrik perbandingan kriteria akan disajikan pada gambar 1 berikut ini:

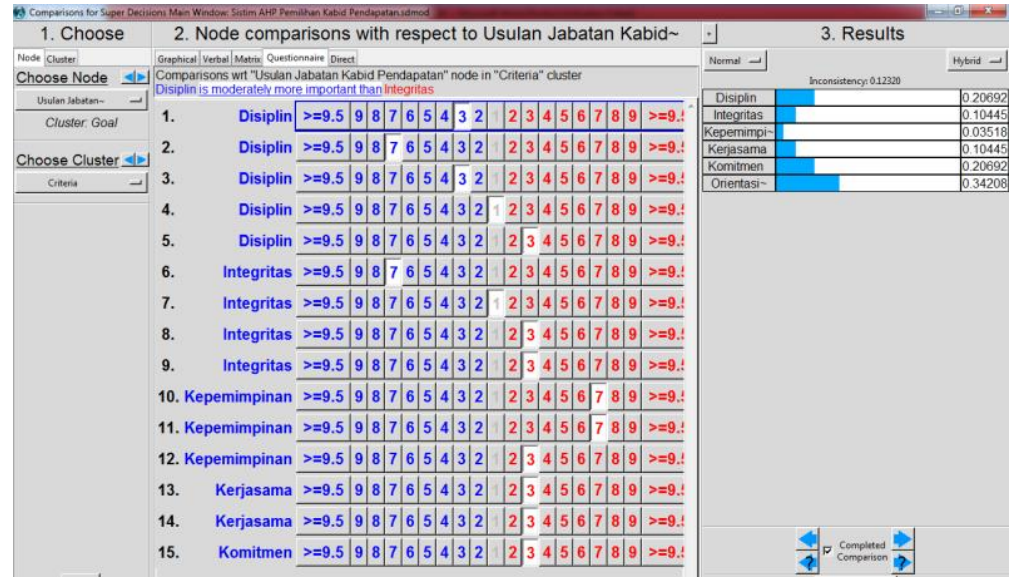

Gambar 2. Matrik Penilaian Kriteria

Berdasarkan hasil dari gambar 1 dapat kita lihat bahwa dari matrik kriteria di dapat nilai "Disiplin $=0,20692$ ", "Integritas $=0,10445$ ", "Kepemimpinan = 0,03518", “Kerjasama = 0,10445", "Komitmen =0,20692", "Orientasi Pelayanan = 0,34208". Dari keenam hasil tersebut dapat kita artikan bahwa yang paling penting atau dominan dari kriteria yang dinilai adalah "Orientasi Pelayanan" dengan angka 0,34208 hal ini menunjukkan bahwa kriteria "Orientasi Pelayanan" memiliki tingkat kepentingan 34,21\% dibandingkan dengan ktriteria-kriteria lainnya. Selanjutnya berdasarkan hasil dari pengolahan sistem pada Tabel 2 menunjukkan bahwa kriteria "Disiplin' dan "Komitmen" memiliki tingkat kepentingan yang sama yaitu sebesar 20,69\% dibandingkan dengan kriteria lainnya. Sementara "Integritas dan "Kerjasama" juga memiliki nilai kepentingan yang sama yaitu 10,45\% dibandingkan dengan kriteria lainnya. Dan yang memiliki kepentingan terkecil dari penilaian kriteria ini adalah "Kepemimpinan" yaitu hanya 3,51\% saja dibandingkan dengan kriteria lainnya. Hasil inconsistensy pada matrik kriteria ini berjumlah 1,00.

Kenapa "Orientasi Pelayan" memiliki kepentingan paling dominan? Hal ini dikarena Kabid Pendapatan merupakan bagian dari jajaran manajerial Badan Keuangan Daerah Kota Padangsidempuan, diwadahi oleh suatu organisasi publik yang mempunyai kewajiban dan tugas pokok untuk melayani masyarakat dengan 
sebaik-baiknya. Jadi sangat layak jika "Orientasi Pelayanan” merupakan bagian terpenting dalam penilaian kriteria. Karena hal ini menunjukkan bahwa seluruh jajaran manajerial Badan Keuangan Daerah Kota Padangsidempuan selalu berusaha untuk memberikan pelayanan yang baik kepada masyarakat dan menjadikan pelayanan yang baik sebagai sesuatu yang mutlak mereka lakukan untuk kepentingan masyarakat yang meraka layani.

\subsection{Matrik Perbandingan Alternatif Pada Kriteria Orientasi Pelayanan}

Perbandingan alternatif pada kriteria "Orientasi Pelayanan" akan disajikan pada gambar 2 di bawah ini:

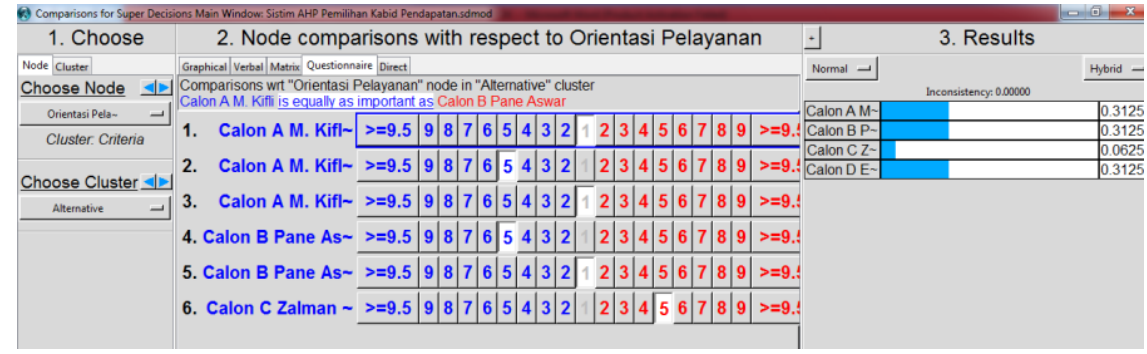

Gambar 3. Matrik Perbandingan Alternatif Pada Kriteria Orientasi Pelayanan

Dari hasil gambar 2 kriteria penilaian "Orientasi Pelayanan" untuk calon A, B dan D memiliki nilai kepentingan yang sama yaitu 31,25\% masing-masingnya dibandingkan calon $\mathrm{C}$. Hal ini menunjukkan bahwa kemampuan untuk pelayanan dimiliki sama pada calon A, B dan D tersebut. Sedangkan calon C hanya memiliki nilai $6,25 \%$ dibandingkan calon lainnya. Nilai inconsistency pada matrik "Orientasi Pelayanan" ini adalah 1,00. Nilai "Orientasi Pelayanan" pada calon A, B dan D sama disebabkan karena ketiga calon ini sebelumnya sudah pernah menduduki jabatan sebagai kabid pada bidang yang lainnya sehingga kemampuan mereka dalam melakukan orientasi pelayanan menjadi lebih baik dibandingkan calon $\mathrm{C}$ yang belum pernah menduduki jabatan kabid sebelumnya.

\subsection{Matrik Perbandingan Alternatif Pada Kriteria Integritas}

Hasil matrik perbandingan alternatif pada kriteria integritas dapat dilihat pada gambar 3 di bawah ini:

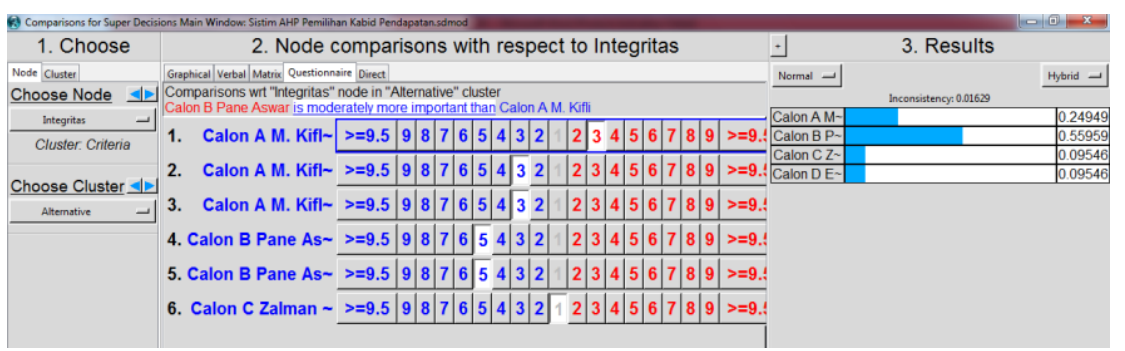

Gambar 4. Matrik Perbandingan Alternatif Pada Kriteria Integritas

Dari gambar 3 dapat kita lihat bahwa nilai "Integritas" dari calon B lebih tinggi dibandingkan calon lainnya yaitu sebesar 55,95\%. Calon A memiliki nilai "Integritas" ke dua tertinggi dari calon B yaitu 24,95\%. Sedangkan calon C dan 
calon D memiliki nilai "Integritas" ke tiga tertinggi dengan nilai yang sama yaitu 9,55\%. Artinya integritas salon B lebih tinggi dari pada tiga calon lainnya. Nilai inconsistency pada matrik "Integritas" ini adalah 1,00.

\subsection{Matrik Perbandingan Alternatif Pada Kriteria Komitmen}

Matrik perbandingan alternatif pada kriteria "Komitmen" dapat dilihat pada gambar 4 di bawah ini:

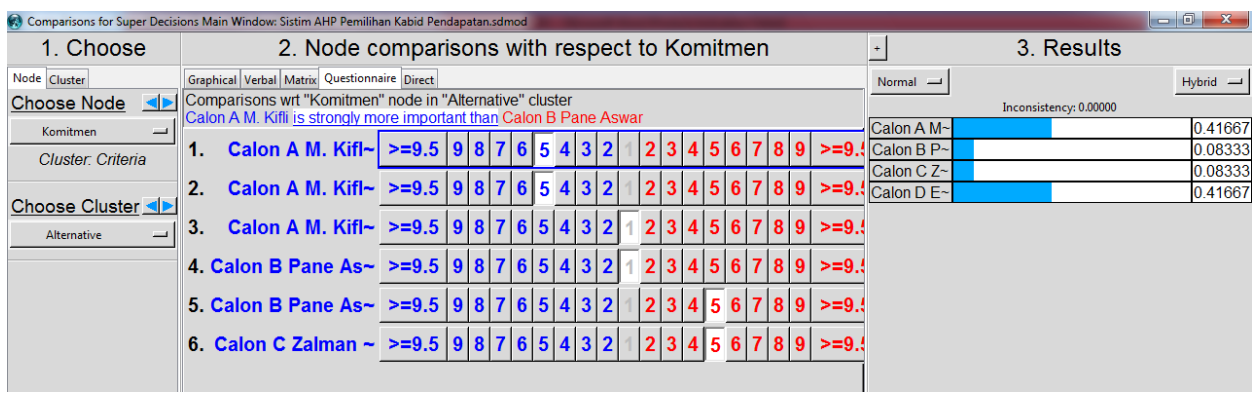

Gambar 5. Matrik Perbandingan Alternatif Pada Kriteria Komitmen

Berdasarkan Tabel 5 di atas dapat kita lihat bahwa calon A dan calon D memiliki nilai "Komitmen" yang sama tinggi. Dan mereka berdua memiliki nilai "Komitmen" tertinggi dibandingkan dua calon lainnya yaitu 41,67\%. Sedangkan calon B dan C memiliki nilai "Komitmen" tertinggi ke dua dengan nilai yang sama pula yaitu 8,33\%. Nilai inconsistency pada matrik "Komitmen" ini adalah 1,00. Nilai komitmen antara A dan D maupun B dan C yang cendrung sama dikarenakan angka penilaian yang dituangkan di dalam Perilaku Kerja (KP) juga cendrung sama. Jadi untuk menghindari pola matrik nilai yang sama dikemudian hari dianjurkan agar ada perbedaan angka penilaian pada setiap calon yang akan diajukan.

\subsection{Matrik Perbandingan Alternatif Pada Kriteria Disiplin}

Matrik perbandingan alternatif pada kriteria "Disiplin" dapat dilihat pada gambar 5 berikut ini:

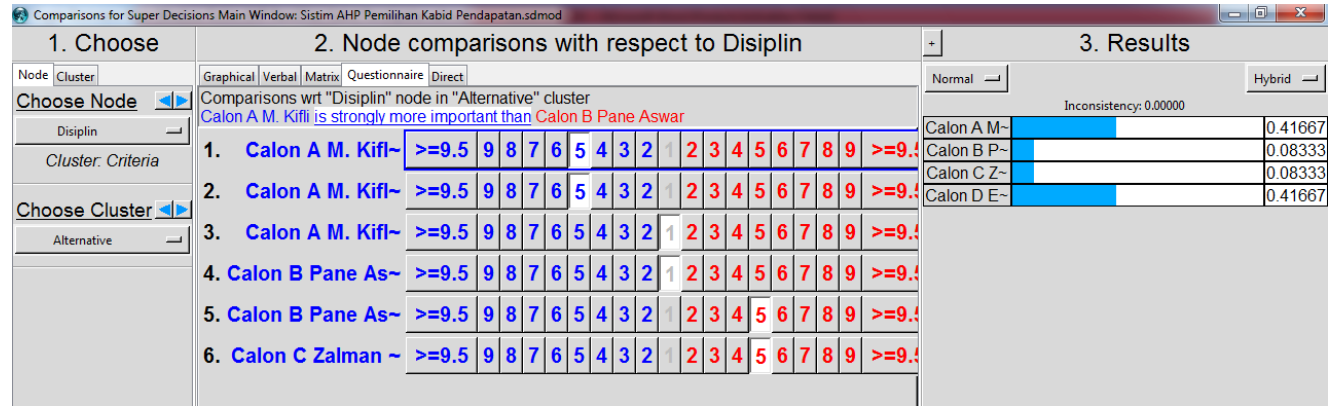

Gambar 6.Matrik Perbandingan Alternatif Pada Kriteria Disiplin

Dari gambar 5 didapat bahwa calon A dan D memiliki nilai "Disiplin" yang sama juga dengan nilai tertinggi dari dua calon lainnya yaitu 41,67\%. Sedangkan calon B dan C memiliki nilai tertinggi ke dua yang sama pula yaitu $8,33 \%$. Nilai inconsistency pada matrik "Disiplin" ini adalah 1,00. Nilai Disiplin antara A dan D maupun $\mathrm{B}$ dan $\mathrm{C}$ yang cendrung sama dikarenakan angka penilaian yang 
dituangkan di dalam Perilaku Kerja (KP) juga cendrung sama. Jadi untuk menghindari pola matrik nilai yang sama dikemudian hari dianjurkan agar ada perbedaan angka penilaian pada setiap calon yang akan diajukan.

\subsection{Matrik Perbandingan Alternatif Pada Kriteria Kerjasama}

Untuk matrik perbandingan alternatif pada kriteria "Kerjasama" dapat dilihat pada gambar 6 berikut:

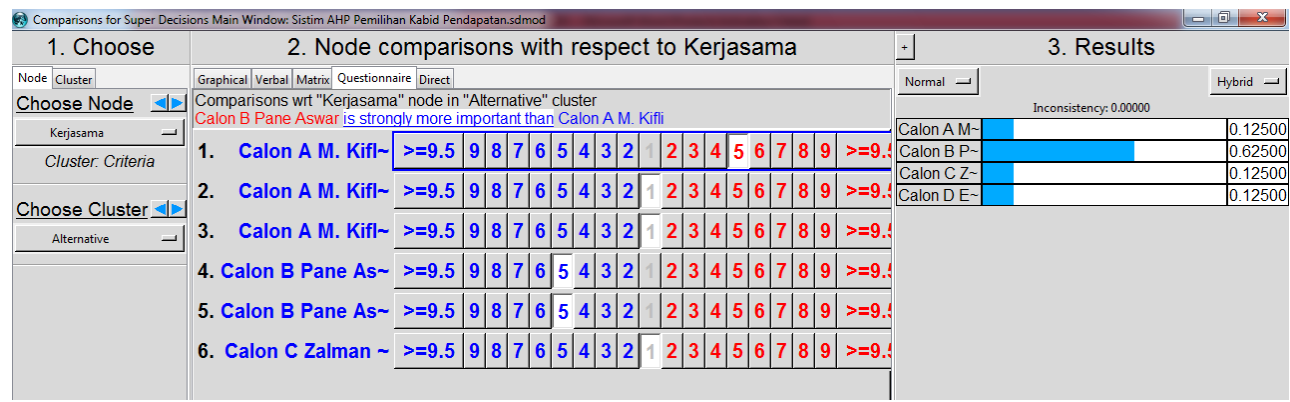

Gambar 7. Matrik Perbandingan Alternatif Pada Kriteria Kerjasama

Berdasarkan gambar 6 dapat kita lihat bahwa calon B memiliki nilai "Kerjasama" tertinggi dibandingkan calon lainnya yaitu sebesar 62,50\%. Sedangkan tiga calon lainnya memiliki nilai "Kerjasama" yang sama yaitu $12,50 \%$. Jadi dalam kerjasama calon B memiliki nilai keunggulan yang jauh lebih tinggi dibandingkan dua calon lainnya. Nilai inconsistency pada matrik "Kerjasama" ini adalah 1,00 .

\subsection{Matrik Perbandingan Alternatif Pada Kriteria Kepemimpinan}

Matrik perbandingan alternatif pada kriteria "Kepemimpinan" dapat dilihat pada gambar 8 berikut ini:

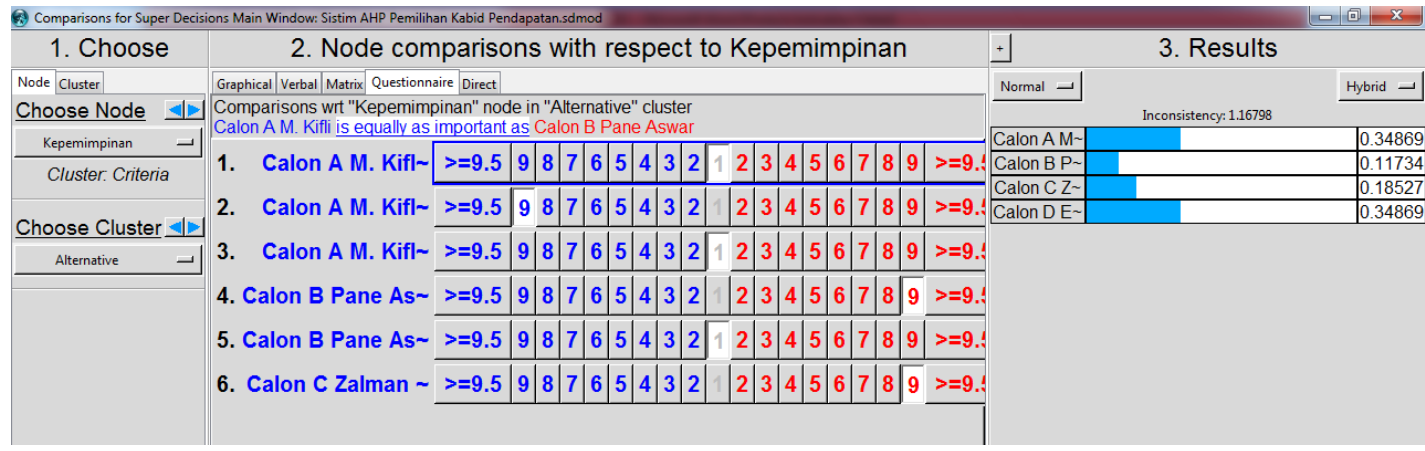

Gambar 8. Matrik Perbandingan Alternatif Pada Kriteria Kepemimpinan

Dari gambar 7 dapat kita lihat bahwa calon A dan D memiliki nilai "Kepemimpinan" yang sama yaitu 34,87\% dibandingkan dua calon lainnya. Dan calon C memiliki nilai tertinggi ke dua yaitu 18,52\%. Sedangkan nilai kepemimpinan terkecil ada pada calon B yaitu 11,74\%. Nilai inconsistency pada matrik "Kerjasama" ini adalah 1,00. 


\subsection{Hasil Komputasi (Computation Result)}

Untuk mendapatkan kesimpulan pilihan dari berbagai alternatif hasil dari sistem komputerisasi yang sudah dilakukan di atas, maka pengambil keputusan dapat membuat pilihan dengan melihat tabel komputasi pada gambar 8 di bawah ini:

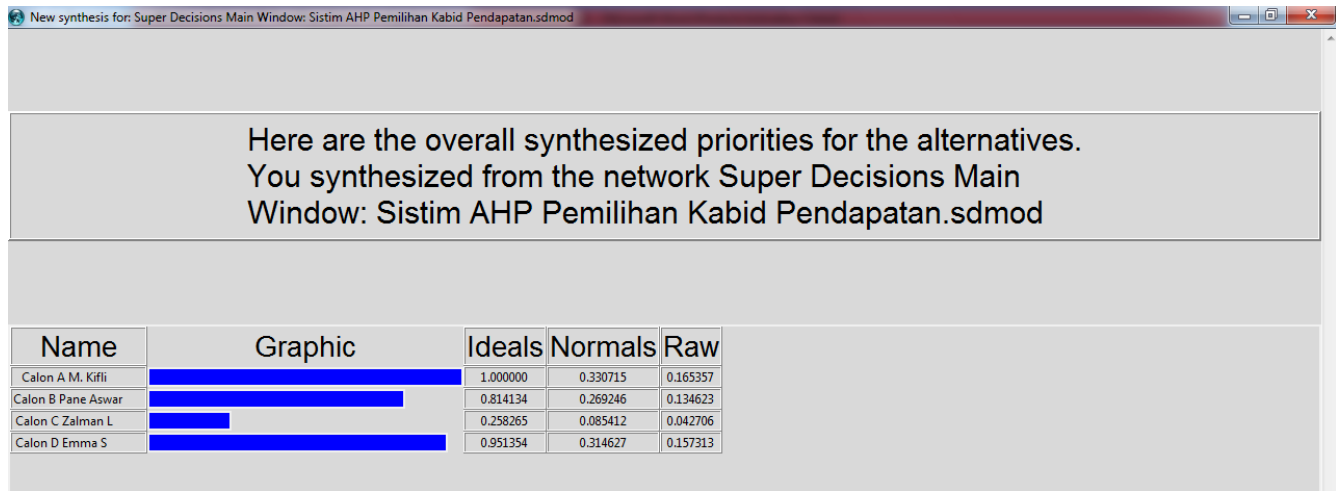

Gambar 9. Hasil Komputasi

Dari hasil komputasi pada gambar 8 dapat dilihat bahwa Calon A merupakan pilihan terbaik dari tiga calon lainnya berdasarkan kriteria-kriteria penilaian yang telah dilakukan di atas. Calon A memiliki nilai komputasi tertinggi yaitu 0.330715 artinya 33,07\% dari total nilai yang ada, calon A memiliki peluang terpilih lebih tinggi dari calon lainnya seperti yang terdapat pada kolom normalitas hasil secara keseluruhan dari semua kriteria yang dinilai. Calon D merupakan calon pilihan ke dua dengan nilai komputasi 0.314627 artinya 31,46\% dari total nilai yang ada, calon D memiliki peluang terpilih kedua lebih tinggi dari calon dua calon lainnya seperti yang terdapat pada kolom normalitas hasil secara keseluruhan dari semua kriteria yang dinilai. Calon B merupakan pilihan yang ke tiga dengan nilai komputasi 0.269246 artinya $26,92 \%$ dari total nilai yang ada, calon C memiliki peluang terpilih lebih tinggi dari satu calon lainnya seperti yang terdapat pada kolom normalitas hasil secara keseluruhan dari semua kriteria yang dinilai. Dan calon $\mathrm{C}$ merupakan pilihan yang ke empat dengan nilai komputasi terkecil yaitu 0.085412 artinya 8,55\% dari total nilai yang ada, calon $\mathrm{C}$ memiliki peluang terpilih paling rendah dari calon lainnya seperti yang terdapat pada kolom normalitas hasil secara keseluruhan dari semua kriteria yang dinilai. Nilai inconsistency normalitas pada hasil komputasi ini adalah 1,00.

Dari hasil akhir keputusan yang bisa diambil berdasarkan komputasi ini dapat kita lihat juga bahwa jumlah nilai dari calon A dan D memiliki perbedaan yang sangat kecil. Ini berarti bahwa kompetensi ke dua calon ini untuk diusulkan menjadi Kabid Pendanaan ini cenderung sama. Tapi ada perbedaan yang sangat kecil yang menunjukkan bahwa calon A memiliki nilai kompetensi yang lebih tinggi untuk diusulkan.

\section{KESIMPULAN}

Dengan menggunakan metode AHP dapat disimpulkan bahwa calon yang terbaik untuk diusulkan berdasarkan kriteria "Perilaku Kerja" (PK) ini adalah calon A. Karena calon A mendapatkan nilai tertinggi dari hasil komputasi yang telah dilakukan dengan metode AHP ini dengan nilai 0.330715 atau 33,07\%. Hasil 
komputerisasi yang sudah dilakukan untuk penerapan metode AHP ini dalam melakukan pengambilan keputusan pada instansi pemerintahan Badan Keuangan Daerah Kota Padangsidempuan sangat baik digunakan. Karena terbukti lebih praktis, lebih tersistematis, lebih terstruktur, dan sangat objektif.

\section{DAFTAR PUSTAKA}

[1] Daihani, D. Umar, Komputerisasi Pengambilan Keputusan,. Jakarta: PT. Elex Media Komputindo, 2001.

[2] A. Paramita, F. A. Mustika, and N. Farkhatin, "Aplikasi Sistem Pendukung Keputusan Guru Terbaik Berdasarkan Kinerja dengan Metode Analytical Hierarchy Process ( AHP ),” vol. 03, no. 01, pp. 9-18, 2017.

[3] S. Wahyuningsih, "Sistem Pendukung Keputusan Untuk Penilaian Kinerja Pegawai Menggunakan Metode Analytical Hierarchy Process ( Ahp ) Pada RSUD Serang," no. 1, pp. 33-37, 2014

[4] R. T. Andriagus, "Sistem pendukung keputusan untuk menentukan kualitas stasiun televisi sebagai konsumsi terbaik bagi masyarakat dengan menggunakan metode ahp," vol. 1, pp. 68-73, 2017.

[5] T. L. Saaty, "Decision making with the analytic hierarchy process,” vol. 1, no. 1, 2008. 